\title{
Morphometric variation, genetic diversity and allelic polymorphism of an underutilised species Thaumatococcus daniellii population in Southwestern Nigeria
}

\author{
David Adedayo Animasaun - Azeez Afeez Peter Adeolu Adedibu - Feyisayo Priscilla Akande Stephen Oyedeji \\ Kehinde Stephen Olorunmaiye
}

Received: 21 May 2020 / Revised: 3 July 2020 / Revised: 15 August 2020 / Accepted: 18 August 2020

(c) Korean Society for Plant Biotechnology

\begin{abstract}
Genetic diversity among Thaumatococcus daniellii populations in the southwestern region of Nigeria were assessed using morphometric and molecular markers to determine the population structure and existing genetic relationship for its improvement, conservation and sustainable utilisation. Populations from five locations in each of the six states were used for the study. Morphometric data were collected on folia characters and analysed for variability. Genome DNA was isolated from the plant leaf and amplified by polymerase chain reaction with inter-simple sequence repeat markers (ISSR) to determine the allelic polymorphism, marker effectiveness and genetic relationship of the population. The results showed significant variations in petiole length and leaf dimensions of the populations within and across the states. These morphometric traits are the major parameters that delimit the populations and they correlated significantly at $\mathrm{P} \leq 0.05$. Analysis of the electrophoregram showed that the ISSR markers are effective for the diversity study. A total of 136 loci were amplified with an average of 7.16 loci per marker, $63.2 \%$ of the loci were polymorphic. The Principal Coordinate Analysis revealed that seven factors accounted for $81.6 \%$ of the variation and the dendrogram separated the populations into two major groups at a genetic distance of 10 (about 90\% similarity) with sub-groups and clusters. Most populations within the state had a high degree of similarity, nonetheless, strong genetic relationship exists among populations from different states. The close relationship between populations across the states suggests a common progenitor,
\end{abstract}

D. A. Animasaun $(\triangle) \cdot$ A. Afeez $\cdot$ P. A. Adedibu $\cdot$ F. P. Akande S. Oyedeji $\cdot$ K. S. Olorunmaiye

Department of Plant Biology, Faculty of Life Sciences, University of Ilorin, P. M. B. 1515, Ilorin, Kwara State, Nigeria

e-mail: animasaun.ad@unilorin.edu.ng which are likely separated by ecological or geographical isolation mechanisms.

Keywords Dendrogram, ecotypes, genetic diversity, morphological variation, percentage polymorphism, population structure

\section{Introduction}

Thaumatococcus daniellii (Benn.) Benth. also known as 'miraculous berry' or 'sweet prayer-plant' is a wild edible herb of the family Maranthaceae native to west Africa rain forest from where it was introduced to Asia and Australia (Arowosoge and Popoola 2006; Csurches and Edward 1998). Although it grows in the wild, it occurs as undergrowth in cocoa, coffee, kola nut and rubber plantations in Nigeria, Ghana and Cote d'Ivoire (Boadi 2011) where the plant is widely distributed in secondary forests with humid conditions. T. daniellii is a perennial, rhizomatous monocotyledon which grows up to $2 \mathrm{~m}$ high and is capable of self-regeneration after harvest. The petiole terminates into a single tough, almost round and versatile leaf that is about 30 35 $\mathrm{cm}$ wide and $40 \sim 50 \mathrm{~cm}$ long, depending on the habitat and age of the plant (Makinde and Taiwo 2004). The flower usually found on the petiole base may be simple or forked with spikes which are bracted and about $8 \sim 10 \mathrm{~cm}$ in length (Fig. 1). Flowers occur throughout the year, but more intensely from July-October. The fruit mature and ripe around January-April (Onwueme et al. 1979).

T. daniellii fruit contains a few shiny black seeds covered in a fleshy red aril. The fruit possesses a non-toxic, intensely sweet protein called thaumatin, which is about 3000 times sweeter than sucrose (Elemo et al. 2001; Van Der Wel and Loeve 1972). Thaumatin is used as a sweetener in pharma- 


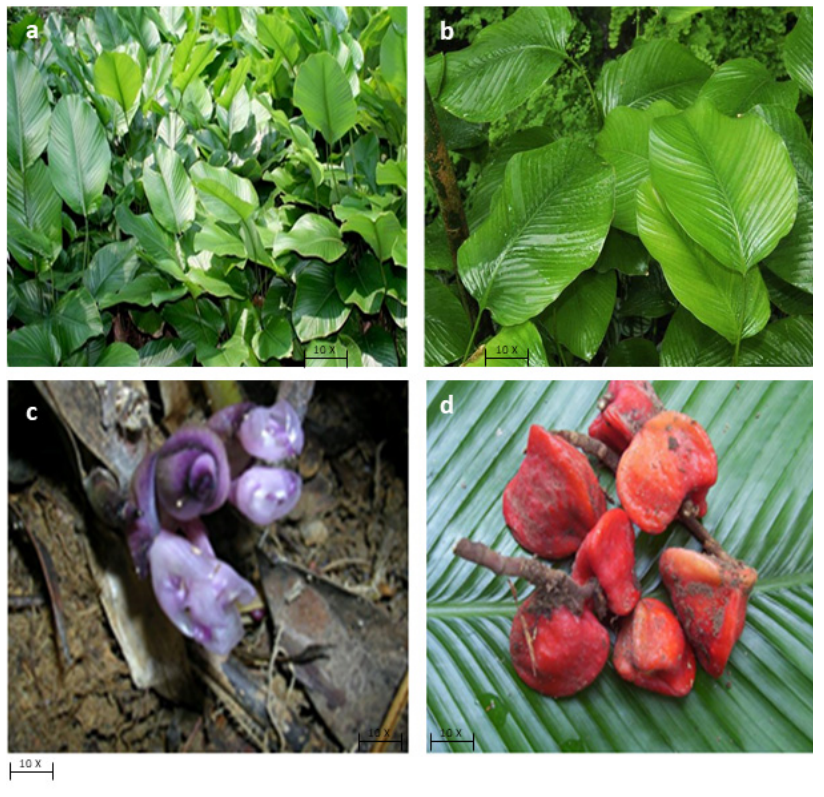

Fig. 1 Morphological features of Thaumatococcus daniellii (a-b) the petiole terminates into a single tough, almost round and versatile leaf (c) the flower at the basal part of the petiole, and (d) mature ripe fruits

ceutical, beverages and confectioneries industries, also as an ideal sweetener for diabetics (Makinde and Taiwo 2004). The plant parts are used by local people for many purposes (Adeyemi et al. 2014; Arowosoge and Popoola 2006; Ndikwe et al. 2014; Ogunsanwo et al. 2012). Due to the ability of the leaf to impacts a characteristic taste into foods, the leaf is used in Nigeria for wrapping and preservation of food materials (Sotannde and Oluwadare 2014). Also, in some parts of the United States and South America where the plant is considered exotic, the leaves are used for food packaging and flavour enhancing (Thorn 2004). Among some folks in West Africa, the fruit is used for sweetening bread, over-fermented palm wine and sour foods (Sofowora 1993; Swift et al. 2002), the straw for making mats, hats, baskets and fish traps (Arowosoge and Popoola 2006; Yeboah et al. 2003) and the roots for the treatment of different ailments (Adebisi et al. 2010; Ojekale et al. 2007). The seeds of $T$. daniellii produce a gel that swells to 10 times its weight and hence could be used as a substitute for agar (Onwueme et al. 1979).

In recent time, the dwindling economy and drastic fall in petroleum price have made life tougher for low-income Nigerians. Sustainable utilization of $T$. daniellii could be a panacea in poverty reduction and improving the microeconomy of the rural dwellers where the plant grows in abundance (Boadi 2011; Ndukwe et al. 2014). Across the populations and microclimatic range, there could be remarkable diversity in leaf characters and the genetic system of the plant. The biodiversity and genetic variations among the populations of $T$. daniellii in Nigeria have not been well documented, at present, the plant genetic diversity is poorly understood. Consequently, the plant remains one of the underutilized and unimproved genetic resources in West Africa (Boadi 2011).

A molecular approach to genetic analysis of plant populations and genotypes is more effective than morphological markers, because it directly accesses the hereditary information for understanding the existing relationships between individuals (Paterson et al. 1991; Williams et al. 1990). The use of molecular markers has proved to be reliable, simple and versatile techniques of genetic diversity profiling. Therefore, they have been used in genetic diversity, identification and genotyping studies of species or natural populations. (Animasaun et al. 2015; Mohapatra and Rout 2005). There little is information on physiological and agronomic aspects of T. daniellii (Boadi 2011; Most et al. 1978; Ndukwe et al. 2014). Scanty literature is available on its nutritional analysis (Agwu et al. 2014; Van Der Wel and Loeve 1972), chemical composition (Chinedu et al. 2014; Elemo et al. 2011) and stalks fibre content (Sotannde and Oluwadare 2014). However, information on the genetic diversity analysis of $T$. daniellii population in Nigeria using a combination of morphological and molecular markers is presently not available. For effective conservation of this plant, analysis of genetic diversity of the available population is essential. This will also help in the development of new cultivars with promising agronomic traits and to maintain the gene pool to enhance its exploitation. Therefore, the present study assessed genetic variations among $T$. daniellii population in Western Nigeria using morphology and molecular markers to provide baseline information for enhanced utilization, conservation and improvement that will promote the economy of the rural people where it is grown.

\section{Material and Methods}

\section{Study Location}

The sample area was Southwest Nigeria which consists of six states (Fig 2). The states fall within the rain forest zone of the country. Samples were studied on five selected locations in each of the states. The T. daniellii plantation in all the selected locations have not been harvested for a year, so the plantations were at full stage of growth. The locations included farms, riversides and open range based on abundance, economic and ethnomedicinal utilisations (Table 1). The geographical position of the locations was 


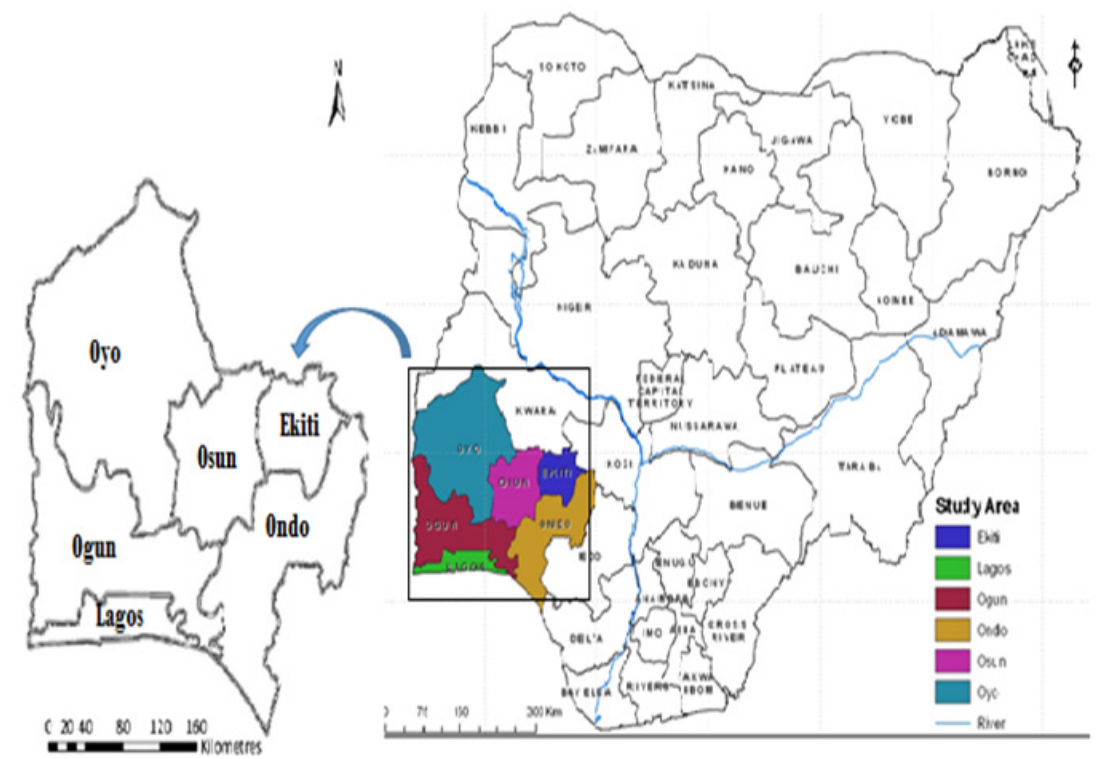

Fig. 2 Map of Nigeria showing the six the western States of Nigeria from where Thaumatococcus daniellii were collected for the morphometric and genetic diversity study

Table 1 Geographical locations of the selected towns and villages for genetic diversity study of Thaumatococcus daniellii populations in the southwest Nigeria

\begin{tabular}{|c|c|c|c|c|}
\hline Locations & Population code & States & $\mathrm{LGA}^{\dagger}$ & Coordinates \\
\hline Mosabi & TdOs01 & Osun & Iwo & $7050^{\prime} 0^{\prime \prime} \mathrm{N}-4069^{\prime} 6^{\prime \prime} \mathrm{E}$ \\
\hline Oke-oba & TdOs02 & Osun & Iwo & $5043^{\prime} 15^{\prime \prime} \mathrm{N}-4 \mathrm{o} 22^{\prime} 0^{\prime \prime} \mathrm{E}$ \\
\hline Ola-teju & TdOs03 & Osun & Iwo & $5041^{\prime} 18^{\prime \prime} \mathrm{N}-11 \mathrm{o} 29^{\prime} 15^{\prime \prime} \mathrm{E}$ \\
\hline Okuku & TdOs04 & Osun & Odo-Otin & $8^{\circ} 8^{\prime} 57^{\prime \prime} \mathrm{N}-4^{\circ} 24^{\prime} 59^{\prime \prime} \mathrm{E}$ \\
\hline Erin-Ijesha & TdOs05 & Osun & Oriade & $7^{\circ} 56^{\prime} 52^{\prime \prime} \mathrm{N}-4^{\circ} 90^{\prime} 22^{\prime \prime} \mathrm{E}$ \\
\hline Iyana-Offa & TdOy01 & Оуо & Lagelu & $7^{\circ} 50^{\prime} 05^{\prime \prime} N-4^{\circ} 07^{\prime} 47^{\prime \prime} \mathrm{E}$ \\
\hline Ile igbon & TdOy02 & Oyo & Lagelu & $7^{\circ} 29^{\prime} 0^{\prime \prime} \mathrm{N}-4^{\circ} 5^{\prime} 0^{\prime \prime} \mathrm{E}$ \\
\hline Lalupon & TdOy03 & Oyo & Lagelu & $7^{\circ} 28^{\prime} 0^{\prime \prime} \mathrm{N}-4^{\circ} 4^{\prime} 0^{\prime \prime} \mathrm{E}$ \\
\hline Dabiri & TdOy04 & Oyo & Akinyele & $7^{\circ} 31^{\prime} 54^{\prime \prime} \quad N-3^{\circ} 56^{\prime} 57^{\prime \prime} \mathrm{E}$ \\
\hline Odo Oba Ejemu & TdOy05 & Oyо & Oyo East & $7^{\circ} 50^{\prime} 59^{\prime \prime} \mathrm{N}-4^{\circ} 4^{\prime} 0^{\prime \prime} \mathrm{E}$ \\
\hline Emuren & $\mathrm{TdOg} 01$ & Ogun & Shagamu & $6^{\circ} 42^{\prime} 0^{\prime \prime} \mathrm{N}-3^{\circ} 37^{\prime} 0^{\prime \prime} \mathrm{E}$ \\
\hline Odo-owa & $\mathrm{TdOg} 02$ & Ogun & Shagamu & $6027^{\prime} 27^{\prime \prime} N-3028^{\prime} 15^{\prime \prime} \mathrm{E}$ \\
\hline Igbafa & $\mathrm{TdOg} 03$ & Ogun & Shagamu & $60.23^{\prime} 30^{\prime \prime} \mathrm{N}-3027^{\prime} 10^{\prime \prime} \mathrm{E}$ \\
\hline Ijebu Ife & $\mathrm{TdOg} 04$ & Ogun & Ijebu East & $6^{\circ} 47^{\prime} 0^{\prime \prime} \mathrm{N}-4^{\circ} 2^{\prime} 0^{\prime \prime} \mathrm{E}$ \\
\hline Owode Egba & $\mathrm{TdOg} 05$ & Ogun & Obafemi Owode & $6^{\circ} 57^{\prime} 42^{\prime \prime} \mathrm{N}-3^{\circ} 30^{\prime} 15^{\prime \prime} \mathrm{E}$ \\
\hline Imota, Ikorodu. & TdLg01 & Lagos & Ikorodu & $6^{\circ} 40^{\prime} 0^{\prime \prime} \mathrm{N}-3^{\circ} 40^{\prime} 0^{\prime \prime} \mathrm{E}$ \\
\hline Igbodu & TdLg02 & Lagos & Epe & $6^{\circ} 38^{\prime} 0^{\prime \prime} \mathrm{N}-3^{\circ} 55^{\prime} 0^{\prime \prime} \mathrm{E}$ \\
\hline Agura-gberigbe & TdLg03 & Lagos & Ikorodu & $6^{\circ} 34^{\prime} 0^{\prime \prime} \mathrm{N}-3^{\circ} 38^{\prime} 0^{\prime \prime} \mathrm{E}$ \\
\hline Agbowa & TdLg04 & Lagos & Epe & $6^{\circ} 39^{\prime} 0^{\prime \prime} \mathrm{N}-3^{\circ} 43^{\prime} 0^{\prime \prime} \mathrm{E}$ \\
\hline Ejinrin & TdLg05 & Lagos & Epe & $6^{\circ} .15^{\prime} 39^{\prime \prime} \mathrm{N}-3^{\circ} 39^{\prime} 35^{\prime \prime} \mathrm{E}$ \\
\hline Boluwatife & TdOn01 & Ondo & Odigbo & $6025^{\prime} 15^{\prime \prime} \mathrm{N}-4035^{\prime} 30^{\prime \prime} \mathrm{E}$ \\
\hline Illara & TdOn02 & Ondo & Ifedore & $7^{\circ} 20^{\prime} 53^{\prime \prime} \mathrm{N}-5^{\circ} 06^{\prime} 52^{\prime \prime} \mathrm{E}$ \\
\hline Ayegun & TdOn03 & Ondo & Odigbo & $7020^{\prime} 45^{\prime \prime} \mathrm{N}-5 \mathrm{o} 20^{\prime} 5^{\prime \prime} \mathrm{E}$ \\
\hline Ipogun & TdOn04 & Ondo & Ifedore & $7^{\circ} 18^{\prime} 53^{\prime \prime} \mathrm{N}-5^{\circ} 04^{\prime} 48^{\prime \prime} \mathrm{E}$ \\
\hline Oka-Akoko & TdOn05 & Ondo & Akoko-South & $7^{\circ} 27^{\prime} 0^{\prime \prime} \mathrm{N}-5^{\circ} 48^{\prime} 0^{\prime \prime} \mathrm{E}$ \\
\hline Ayetoro-Ekiti & TdEk01 & Ekiti & Moba & $7^{\circ} 15^{\prime} 59^{\prime \prime} N-5^{\circ} 14^{\prime} 56^{\prime \prime} \mathrm{E}$ \\
\hline Ipoti-Ekiti & TdEk02 & Ekiti & Ijero & $7^{\circ} 27^{\prime} 15^{\prime \prime} \mathrm{N}-5^{\circ} 07^{\prime} 29^{\prime \prime} \mathrm{E}$ \\
\hline Igogo-Ekiti & TdEk03 & Ekiti & Moba & $7^{\circ} 22^{\prime} 90^{\prime \prime} \mathrm{N}-5^{\circ} 11^{\prime} 15^{\prime \prime} \mathrm{E}$ \\
\hline Oke-Imesi Ekiti & TdEk04 & Ekiti & Ekiti West & $7^{\circ} 49^{\prime} 0^{\prime \prime} \mathrm{N}-4^{\circ} 55^{\prime} 0^{\prime \prime} \mathrm{E}$ \\
\hline Ogotun-Ekiti & TdEk05 & Ekiti & Ekiti South-West & $7^{\circ} 30^{\prime} 0^{\prime \prime} \mathrm{N}-5^{\circ} 0^{\prime} 0^{\prime \prime} \mathrm{E}$ \\
\hline
\end{tabular}

${ }^{\dagger}$ Key: LGA $=$ Local Government Area where the site of collections were located. 
determined with the aid of Garmin Global Position Satellite (GPS) device (GPSMAP 60csx, Garmin, USA). The soil properties for the study locations have been described (Fagbemi and Shogunle 1995; Gbadegesin and Olabode 2000; Nwachokor and Uzu 2008).

\section{Morphometric Studies}

Twenty stands of $T$. daniellii were randomly selected by selecting a stand at every $2 \mathrm{~m}$ distance on $40 \mathrm{~m}$ a zigzag line in each location. Petiole length (stalk), leave length, and leaf breadth was measured using tape rule (Stanley, UK) while petiole diameter and leaf thickness were determined with electronic Vernier calliper (ATD-8656). Folia related morphological data obtained were subjected to analysis of variance (ANOVA) using SPSS version 20 statistical package for Windows Operating system. The means were compared and separated with the New Duncan Multiple Range Test (NDMRT). Also, the correlations and association between the morphological traits were determined at $\mathrm{P}<0.05$ and $\mathrm{P}<0.01$ significant levels. Biplot analysis was conducted with PAST software (ver 3.5) to reveal the separation of the populations into distinct groups based on morphometric traits.

\section{Genomic DNA Extraction}

Genomic DNA (gDNA) was extracted from young fully expanded leave of a $T$. daniellii plant randomly selected for morphometric study in each of the location using Plant DNA Extraction Kit (Zymo Research, USA) following manufacturer's protocol. Quality of the gDNA was determined by $0.8 \%$ agarose gel electrophoresis and visualized with UV light. The concentration was determined using Nanodrop 8000 spectrophotometer (Thermo Scientific, USA).

Polymerase Chain Reaction (PCR) analysis

PCR amplification of the gDNA was performed with thermocycler (Applied Biosystems; USA) using ISSR primers. Each reaction mixture contained 50 ng gDNA, 1 unit of Taq polymerase (Thermofisher, USA), 1X PCR buffer consisting of $2.5 \mathrm{mM} \mathrm{MgCl}_{2}$ and $200 \mu \mathrm{M}$ of each dNTP mixture (Thermofisher, USA) and 10 pmol of the ISSR primer (Eurofins, Germany) was made up to $25 \mu$ reaction volume by addition of double distilled water. The cycling condition was as described by Animasaun et al. (2015). The amplicons were resolved on $1.5 \%$ agarose gel stained with ethidium bromide in $1 \mathrm{X}$ TAE buffer ran at $100 \mathrm{~V}$ for $45 \mathrm{~min} .1 \mathrm{~Kb}$ gene ruler (Fermentas, USA) was used as a standard fragment size for comparison. The electrophoresed gel was viewed under UV transmulator and photographed by a gel documentation system (Biorad, USA).

Data analysis

Fragment analysis was carried out by similarity index, distinct and reproducible band from the electrophoregrams anticipated by the standard DNA ruler (DNA ladder) were scored as ' 1 ' for presence and ' 0 ' for absence. The data were entered into binary matrix format for diversity analysis. The allele frequency were evaluated from the electrophoregrams and the marker efficiency determined by percentage polymorphism. The Polymorphic information content (PIC) were calculated for each primer adopting the formula of Botstein et al. (1980) and a matrix generated. Principal coordinate (PCO) analysis was performed using (PAST ver 3.5). Cluster analysis was performed by an agglomerative technique using the unweighted pair group method of arithmetic average (UPGMA) algorithm method in NTSYS-pc version 2.1 (Numerical taxonomy and multivariate analysis system) software package. The genetic diversity and relationships within and between the populations were graphically presented as dendrogram.

\section{Results}

To explore population structure and genetic diversity and of Thaumatococcus daniellii, morphometric and inter-simple sequence repeat markers were employed. The results showed morphometric variations among T. Daniellii populations collected from different locations in the six southwest Nigeria states (Table 2). The petiole length varied significantly $(\mathrm{P}<0.05)$ within and across the sampled states. It ranged from $65.02 \sim 98.30 \mathrm{~cm}, 61.74 \sim 94.06 \mathrm{~cm}, 71.61 \sim 99.30 \mathrm{~cm}$, $72.20 \sim 98.26 \mathrm{~cm}, 87.30 \sim 111.30 \mathrm{~cm}$ and $89.24 \sim 118.32 \mathrm{~cm}$ for Osun, Oyo, Ogun, Lagos, Ondo and Ekiti population respectively. The population from Ogotun-Ekiti (TdEk05) was the tallest with a mean value of $118.32 \mathrm{~cm}$, followed by TdOn04, an Ondo population with mean petiole length of $111.30 \mathrm{~cm}$ and the shortest plants $(61.76 \mathrm{~cm})$ occurred in TdOy03; a population from Lalupon, Oyo state. Also, leaf breadth and length varied significantly among the population within and across the states. The populations; TdEk05 (OgotunEkiti), TdEk03 (Igogo-Ekiti) TdOn03 (Ayegun) had very broad leaves $(>35<40 \mathrm{~cm})$. Most of the populations had broad 
Table 2 Folia morphometric characters of Thaumatococcus daniellii population from southwest region of Nigeria

\begin{tabular}{|c|c|c|c|c|c|c|}
\hline State & Population code & PL $(\mathrm{cm})$ & LW (cm) & $\mathrm{LL}(\mathrm{cm})$ & LT $(\mathrm{cm})$ & PD $(\mathrm{cm})$ \\
\hline \multirow{4}{*}{ Osun } & TdOs01 & $98.30 \pm 6.91^{\mathrm{bc}}$ & $29.22 \pm 2.65^{\mathrm{cd}}$ & $41.68 \pm 3.21^{\mathrm{bc}}$ & $0.04 \pm 0.01^{\mathrm{ab}}$ & $0.78 \pm 0.08^{\text {cd }}$ \\
\hline & TdOs02 & $65.02 \pm 3.98^{f}$ & $33.02 \pm 3.17^{\mathrm{ab}}$ & $44.64 \pm 3.99^{\mathrm{bc}}$ & $0.05 \pm 0.01^{\mathrm{a}}$ & $0.82 \pm 0.06^{\mathrm{bc}}$ \\
\hline & TdOs03 & $78.46 \pm 5.85^{\mathrm{e}}$ & $29.24 \pm 2.65^{\mathrm{cd}}$ & $34.00 \pm 2.37^{\mathrm{e}}$ & $0.05 \pm 0.01^{\mathrm{a}}$ & $0.96 \pm 0.07^{\mathrm{a}}$ \\
\hline & TdOs04 & $94.02 \pm 6.81^{\mathrm{cd}}$ & $27.02 \pm 2.17^{\mathrm{cd}}$ & $44.16 \pm 3.99^{b c}$ & $0.06 \pm 0.01^{\mathrm{a}}$ & $0.82 \pm 0.07^{\mathrm{bc}}$ \\
\hline \multirow{6}{*}{ Oyo } & TdOs05 & $86.16 \pm 6.35^{\text {de }}$ & $32.24 \pm 3.11^{\mathrm{bc}}$ & $39.00 \pm 2.57^{\mathrm{d}}$ & $0.05 \pm 0.01^{\mathrm{a}}$ & $0.96 \pm 0.08^{\mathrm{a}}$ \\
\hline & TdOy01 & $83.36 \pm 6.13^{\mathrm{de}}$ & $32.96 \pm 3.15^{\mathrm{bc}}$ & $42.56 \pm 3.54^{\mathrm{bc}}$ & $0.06 \pm 0.01^{\mathrm{a}}$ & $0.81 \pm 0.06^{\mathrm{bc}}$ \\
\hline & TdOy02 & $91.44 \pm 6.72^{\mathrm{cd}}$ & $30.08 \pm 3.01^{\mathrm{bc}}$ & $42.58 \pm 3.21^{\mathrm{bc}}$ & $0.05 \pm 0.01^{\mathrm{b}}$ & $0.66 \pm 0.07^{\mathrm{e}}$ \\
\hline & TdOy03 & $61.76 \pm 3.60^{\mathrm{fg}}$ & $27.47 \pm 2.17^{\mathrm{cd}}$ & $40.14 \pm 3.17^{\mathrm{cd}}$ & $0.05 \pm 0.01^{b}$ & $0.78 \pm 0.09^{\mathrm{cd}}$ \\
\hline & TdOy04 & $94.06 \pm 6.81^{\mathrm{cd}}$ & $33.02 \pm 3.17^{\mathrm{ab}}$ & $44.14 \pm 3.89^{\mathrm{bc}}$ & $0.06 \pm 0.01^{\mathrm{a}}$ & $0.82 \pm 0.07^{\mathrm{bc}}$ \\
\hline & TdOy05 & $69.08 \pm 5.08^{\mathrm{ef}}$ & $33.46 \pm 3.19^{\mathrm{ab}}$ & $41.64 \pm 3.21^{\mathrm{cd}}$ & $0.05 \pm 0.01^{\mathrm{a}}$ & $0.82 \pm 0.08^{\mathrm{bc}}$ \\
\hline \multirow{4}{*}{ Ogun } & TdOg01 & $71.61 \pm 5.16^{\mathrm{ef}}$ & $26.52 \pm 2.17^{\mathrm{d}}$ & $39.52 \pm 2.21^{\mathrm{d}}$ & $0.04 \pm 0.01^{\mathrm{ab}}$ & $0.62 \pm 0.06^{\mathrm{e}}$ \\
\hline & $\mathrm{TdOg} 02$ & $89.30 \pm 6.60^{\mathrm{d}}$ & $33.90 \pm 3.17^{\mathrm{ab}}$ & $45.80 \pm 3.65^{\mathrm{ab}}$ & $0.05 \pm 0.01^{\mathrm{a}}$ & $0.52 \pm 0.05^{\mathrm{f}}$ \\
\hline & $\mathrm{TdOg} 03$ & $78.78 \pm 5.88^{\mathrm{e}}$ & $30.82 \pm 3.04^{\mathrm{bc}}$ & $42.60 \pm 3.54^{\mathrm{cd}}$ & $0.05 \pm 0.01^{\mathrm{a}}$ & $0.74 \pm 0.04^{\mathrm{cd}}$ \\
\hline & $\mathrm{TdOg} 04$ & $99.30 \pm 6.90^{\mathrm{bc}}$ & $29.90 \pm 2.70^{\mathrm{cd}}$ & $41.80 \pm 3.21^{\mathrm{cd}}$ & $0.06 \pm 0.01^{\mathrm{a}}$ & $0.52 \pm 0.05^{\mathrm{f}}$ \\
\hline \multirow{6}{*}{ Lagos } & TdOg05 & $88.12 \pm 6.65^{d}$ & $32.82 \pm 3.14^{\text {bc }}$ & $44.60 \pm 3.89^{b c}$ & $0.05 \pm 0.01^{\mathrm{a}}$ & $0.74 \pm 0.09^{\text {cd }}$ \\
\hline & TdLg01 & $72.20 \pm 5.23^{\mathrm{ef}}$ & $29.38 \pm 2.54^{\mathrm{cd}}$ & $41.00 \pm 3.46^{\mathrm{cd}}$ & $0.05 \pm 0.01^{\mathrm{a}}$ & $0.71 \pm 0.05^{\mathrm{de}}$ \\
\hline & TdLg02 & $81.26 \pm 6.02^{\mathrm{de}}$ & $28.26 \pm 2.43^{\mathrm{cd}}$ & $42.82 \pm 3.54^{\mathrm{cd}}$ & $0.04 \pm 0.01^{\mathrm{ab}}$ & $0.88 \pm 0.09^{\mathrm{ab}}$ \\
\hline & TdLg03 & $97.70 \pm 6.98^{\mathrm{bc}}$ & $32.30 \pm 2.45^{\mathrm{bc}}$ & $47.86 \pm 4.01^{\mathrm{a}}$ & $0.05 \pm 0.01^{\mathrm{a}}$ & $0.68 \pm 0.07^{\mathrm{de}}$ \\
\hline & TdLg04 & $73.20 \pm 7.23^{\mathrm{ef}}$ & $31.38 \pm 3.14^{\mathrm{bc}}$ & $41.02 \pm 3.46^{\mathrm{cd}}$ & $0.05 \pm 0.01^{\mathrm{a}}$ & $0.71 \pm 0.06^{\mathrm{d}}$ \\
\hline & TdLg05 & $98.26 \pm 6.91^{\mathrm{bc}}$ & $31.26 \pm 2.13^{\mathrm{bc}}$ & $43.82 \pm 3.80^{\mathrm{bc}}$ & $0.05 \pm 0.01^{\mathrm{a}}$ & $0.78 \pm 0.08^{\mathrm{cd}}$ \\
\hline \multirow{4}{*}{ Ondo } & TdOn01 & $98.12 \pm 6.90^{\mathrm{bc}}$ & $30.56 \pm 3.06^{\mathrm{bc}}$ & $46.18 \pm 3.68^{\mathrm{ab}}$ & $0.05 \pm 0.01^{\mathrm{a}}$ & $0.88 \pm 0.08^{\mathrm{ab}}$ \\
\hline & TdOn02 & $87.30 \pm 6.18^{\mathrm{d}}$ & $34.30 \pm 3.27^{\mathrm{ab}}$ & $39.46 \pm 2.21^{\mathrm{d}}$ & $0.06 \pm 0.01^{\mathrm{a}}$ & $0.93 \pm 0.08^{\mathrm{ab}}$ \\
\hline & TdOn03 & $104.54 \pm 8.86^{\mathrm{b}}$ & $36.00 \pm 4.19^{\mathrm{a}}$ & $47.28 \pm 4.01^{\mathrm{a}}$ & $0.05 \pm 0.01^{\mathrm{a}}$ & $0.76 \pm 0.08^{\mathrm{cd}}$ \\
\hline & TdOn04 & $111.30 \pm 9.18^{\mathrm{ab}}$ & $34.30 \pm 3.27^{\mathrm{ab}}$ & $45.46 \pm 3.62^{\mathrm{ab}}$ & $0.05 \pm 0.01^{\mathrm{a}}$ & $0.96 \pm 0.12^{\mathrm{a}}$ \\
\hline \multirow{6}{*}{ Ekiti } & TdOn05 & $89.54 \pm 6.86^{\mathrm{d}}$ & $33.00 \pm 3.19^{\mathrm{ab}}$ & $39.28 \pm 2.19^{d}$ & $0.06 \pm 0.01^{\mathrm{a}}$ & $0.94 \pm 0.01^{\mathrm{a}}$ \\
\hline & TdEk01 & $89.24 \pm 6.85^{\mathrm{d}}$ & $30.06 \pm 3.03^{\mathrm{bc}}$ & $39.24 \pm 2.19^{\mathrm{d}}$ & $0.05 \pm 0.01^{\mathrm{a}}$ & $0.87 \pm 0.08^{\mathrm{c}}$ \\
\hline & TdEk02 & $109.06 \pm 7.34^{\mathrm{b}}$ & $34.66 \pm 3.30^{\mathrm{ab}}$ & $48.86 \pm 4.18^{\mathrm{a}}$ & $0.05 \pm 0.01^{\mathrm{a}}$ & $0.79 \pm 0.10^{\mathrm{cd}}$ \\
\hline & TdEk03 & $104.32 \pm 7.47^{b}$ & $35.02 \pm 4.04^{\mathrm{a}}$ & $44.42 \pm 3.58^{\mathrm{bc}}$ & $0.05 \pm 0.01^{\mathrm{a}}$ & $0.91 \pm 0.09^{\mathrm{a}}$ \\
\hline & TdEk04 & $93.06 \pm 6.54^{\mathrm{cd}}$ & $32.66 \pm 3.49^{b c}$ & $38.86 \pm 2.02^{\mathrm{d}}$ & $0.06 \pm 0.01^{\mathrm{a}}$ & $0.79 \pm 0.05^{\mathrm{cd}}$ \\
\hline & TdEk05 & $118.32 \pm 7.47^{\mathrm{a}}$ & $36.46 \pm 3.20^{\mathrm{a}}$ & $49.42 \pm 4.21^{\mathrm{a}}$ & $0.05 \pm 0.01^{\mathrm{a}}$ & $0.90 \pm 0.09^{\mathrm{a}}$ \\
\hline
\end{tabular}

Values with same alphabet(s) along the column were not significantly different at $\mathrm{p}<0.05$. Keys: PL: Petiole length; LW: Leaf width; LL: Leaf length; LT: Leaf thickness; PD: Petiole diameter

leaves (between 30-35 cm), while seven populations; three from Osun, two from Lagos and one each from Oyo and Ogun had leaf breadth less than $30 \mathrm{~cm}$. Meanwhile, the most narrow leaves $(26.52 \mathrm{~cm}$ ) were found among the $\mathrm{TdOg} 01$ (Emuren); a population from Ogun State.

The length of the leaves differs significantly within and across the states (Table 2). The populations TdEk05, TdEk02, $\mathrm{TdOn} 03$ and $\mathrm{TdLg} 03$ produced significantly long leaves while the shortest leaves occurred in TdOs03 (Ola-Teju) population in Osun State. While leaf thickness was similar for all the populations, the petiole diameter varied. However, no population recorded petiole diameter greater than $1 \mathrm{~cm}$. At a probability level of 0.05 , the folia characters studied cross the states showed Ekiti populations had the highest average petiole length followed by Ondo while the least occurred in Oyo (Supplementary Table 1). The trend was similar for leaf dimensions. Whereas leaf thickness was statistically similar for the populations across the states, the petiole diameter was the same except for Ogun populations that had the most slender petioles. The values obtained for petiole length, leaf length, leaf thickness and petiole diameter for the populations were not skewed, which mean that most values were around the median (Supplementary Fig. 1). However, leaf breadth values skewed towards the upper limit, indicating the majority of the populations had vales less than the median in term of leaf breadth. Nevertheless, leaf thickness and petiole diameters were similar for the states. In general, the values obtained for the folia traits of the populations in each of the states had no outliers, as the values were close to the mean.

The result of the biplot analysis revealed that leaf length, leaf width and petiole length are the major parameters that delimit the populations as most populations were marked by these parameters (Fig 3). Some populations from Osun (TdOs02, TdOs03), Oyo (TdOy03, TdOy05), Ogun (TdOg01, TdOg03) and Lagos (TdLg01, TdLg02, 


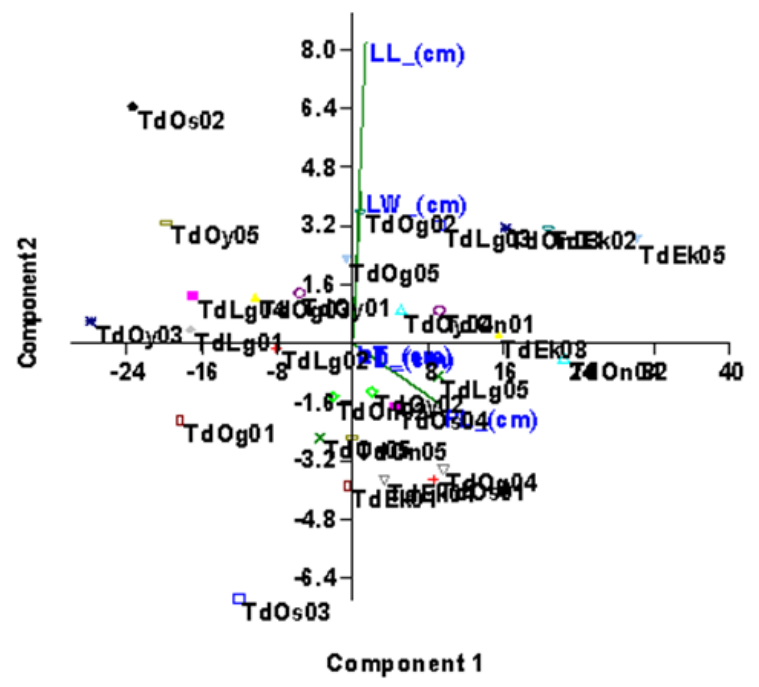

Fig. 3 Biplot analysis of folia morphometric variation of Thaumatococcus daniellii populations from the southwestern region of Nigeria

Table 3 Correlation coefficients of quantitative folia traits of Thaumatococcus daniellii populations collected from Southwestern states of Nigeria

\begin{tabular}{|c|c|c|c|c|c|}
\hline & PL & PD & LW & LL & LT \\
\hline PL & 1 & & & & \\
\hline PT & 0.2613 & 1 & & & \\
\hline LW & $0.6995 * *$ & 0.2534 & 1 & & \\
\hline LL & $0.6704 * *$ & 0.3209 & $0.9563 *$ & 1 & \\
\hline $\mathrm{LT}$ & 0.3950 & 0.1208 & 0.0517 & 0.1179 & 1 \\
\hline
\end{tabular}

Key: PL: Petiole length; PD: Petiole diameter; LW: Leaf width; LL: Leaf length; and, LT: Leaf thickness. **values are significant at $\mathrm{P}<0.05$, and $*$ at $\mathrm{P}<0.01$

TdLg04) in the quadrant II and III were nor properly delimited by the parameters which remarkably partitioned and marked populations from Ekiti and Ondo. The petiole diameter and leaf thickness are weak parameters for delimiting the populations. There are significant positive correlations between petiole length and leaf width (Table 3), also, leaf length and petiole length had positive associate at $\mathrm{P}<0.05$. Furthermore, at $\mathrm{P}<0.01$, a positive association existed between the leaf length and leaf width of the populations.

The amplification information from the ISSR markers revealed that the markers effectiveness in the assessment of the genetic diversity and relationships among the $T$. daniellii populations (Fig. 4). Presence of null alleles was observed in some of the loci analyzed which accounted for low polymorphism and informativeness of such markers. Out of the 19 ISSR markers employed in the study, 14 produced a high average number of effective alleles with

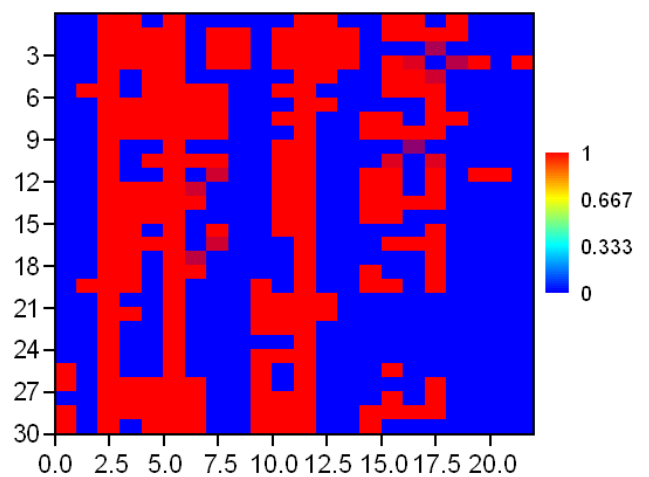

Fig. 4 Amplification matrix and polymorphic information content of nineteen inter-simple sequence repeat markers used for genetic diversity of Thaumatococcus daniellii population from southwestern state of Nigeria.

The $\mathrm{x}$-axis represent the ISSR markers while the $\mathrm{y}$-axis represent the populations

polymorphic information content above 0.5 which is the benchmark for the determination of the marker efficiency. Analysis of the electrophoregrams showed a total of 136 loci and about 2000 alleles were amplified by the markers. The number of loci per marker ranged from 3 to 12, with an average of 7.16 per marker (Table 4). The highest number of loci (12) was produced by ISSR10, followed by ISSR7 and ISSR 4 which amplified 10 fragments each, while ISSR16 marked just 3 loci. The percentage polymorphism of the makers was $63.2 \%$, i.e. 86 out of the 136 total loci amplified were polymorphic. The markers ISSR19 and ISR18 had $100 \%$ polymorphism, seven markers other markers produced polymorphisms $\geq 70 \%$. The least polymorphic marker was ISSR14 (28.6\%). The fragment size of the amplified loci ranged between $100 \sim 2800 \mathrm{bp}$. The marker ISSR10 with the highest number loci amplifications also marked the largest fragment size.

The Principal Coordinate Analysis (PCoA) based on the allelic frequency placed the populations in different quadrants. Seven markers accounted for $81.6 \%$ of the observed genetic diversity. A mixture of eleven populations from Ekiti, Oyo and Lagos congregated on quadrant I (Fig. 5). Interestingly, only two populations (TdEk01 and TdEk03) from Ayetoro-Ekiti and Igogo-Ekiti were found in quadrant II wile five populations from Ondo State occupied quadrant III. The coordinate axis assembled 10 heterogeneous populations comprising of five from Osun, two each from Lagos and Oyo and one from Ogun in quadrant IV.

The dendrogram based on hierarchical diversity matrix and genetic similarity among the $T$. daniellii is presented as Fig. 6. The morphometric and ISSR markers separated the population into two major groups at a genetic distance 
Table 4 Loci and allelic polymorphism generated by inter-simple sequence repeat markers used for genetic diversity of Thaumatococcus daniellii population from southwestern state of Nigeria

\begin{tabular}{|c|c|c|c|c|c|c|c|}
\hline SN & Code & Sequence $\left(5^{\prime}-3^{\prime}\right)$ & NAL & NML & NPL & $\% \mathrm{P}$ & $\mathrm{FZ}(\mathrm{pb})$ \\
\hline 1 & ISSR1 & AGAGAGAGAGAGAGAGT & 7 & 3 & 4 & 57.1 & $1300-400$ \\
\hline 2 & ISSR2 & TGTGTGTGTGTGTGTG & 8 & 3 & 5 & 62.5 & $2000-300$ \\
\hline 3 & ISSR3 & AGCACGAGCAGCAGCGA & 5 & 3 & 2 & 40.0 & $1400-300$ \\
\hline 4 & ISSR4 & AGCACGAGCAGCAGCGG & 10 & 4 & 6 & 60.0 & $1400-400$ \\
\hline 5 & ISSR5 & AGCACGAGCAGCAGCGT & 8 & 5 & 3 & 37.5 & $1100-500$ \\
\hline 6 & ISSR6 & CACACACACACACAAT & 6 & 1 & 5 & 83.3 & $1700-400$ \\
\hline 7 & ISSR7 & CACACACACACACAAC & 10 & 4 & 7 & 70.0 & $1800-300$ \\
\hline 8 & ISSR8 & CACACACACACACAGT & 7 & 3 & 4 & 57.1 & $2000-400$ \\
\hline 9 & ISSR9 & CACACACACACACAGC & 7 & 2 & 5 & 71.4 & $1500-500$ \\
\hline 10 & ISSR10 & GTGTGTGTGTGTGTTG & 12 & 4 & 8 & 66.7 & $2800-300$ \\
\hline 11 & ISSR11 & GTGTGTGTGTGTGTCA & 6 & 3 & 3 & 50.0 & $1600-400$ \\
\hline 12 & ISSR12 & GTGTGTGTGTGTGTCT & 7 & 2 & 5 & 71.4 & $2500-300$ \\
\hline 13 & ISSR13 & GTGTGTGTGTGTGTAT & 8 & 2 & 6 & 75.0 & $1000-100$ \\
\hline 14 & ISSR14 & GCTGAGAGAGAGAGAGA & 7 & 5 & 2 & 28.6 & $1500-300$ \\
\hline 15 & ISSR15 & GCAGAGAGAGAGAGAGA & 5 & 3 & 2 & 40.0 & $1100-300$ \\
\hline 16 & ISSR16 & GAGAGAGAGAGACC & 9 & 2 & 7 & 77.8 & $2100-300$ \\
\hline 17 & ISSR17 & CACACACACACAAG & 5 & 1 & 4 & 80.0 & $1700-100$ \\
\hline 18 & ISSR18 & CAGCACACACACACACA & 5 & 0 & 5 & 100.0 & $1800-500$ \\
\hline 19 & ISSR19 & GTGTGTGTGTGTCC & 3 & 0 & 3 & 100.0 & $1400-400$ \\
\hline \multicolumn{3}{|c|}{ Total } & 136 & 50 & 86 & 63.22 & \\
\hline \multicolumn{3}{|c|}{ Average } & 7.16 & 2.63 & 4.53 & 46.28 & \\
\hline
\end{tabular}

Keys: NAL: Number of amplified loci; NML: Number of monomorphic loci; NPL: Number of polymorphic loci; \%P: Percentage polymorphism; PIC: Polymorphic information content; FZ: Range of amplified fragments

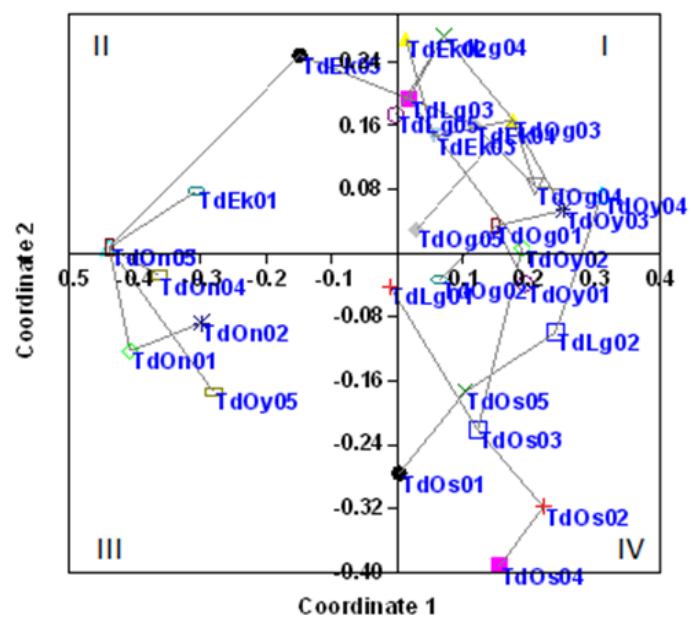

Fig. 5 Principal coordinates partitioning of Thaumatococcus daniellii populations from southwestern region of Nigeria based on allelic data generated from nineteen inter-simple sequence repeat markers

of 10 (about $90 \%$ similarity), with sub-groups and clusters. At a genetic distance of 3, group 1 split into two clusters; $1 \mathrm{~A}$ and $1 \mathrm{~B}$. The $1 \mathrm{~A}$ consisted of four Ondo populations while 1B had one population each from Ekiti, Ondo and Oyo. Group 2 had three sub-groups. Sub-group 2A was further partitioned into two clusters; cluster $2 \mathrm{~A}(\mathrm{i})$ with three members (TdOs02, TdOs03, TdOs04) which are all

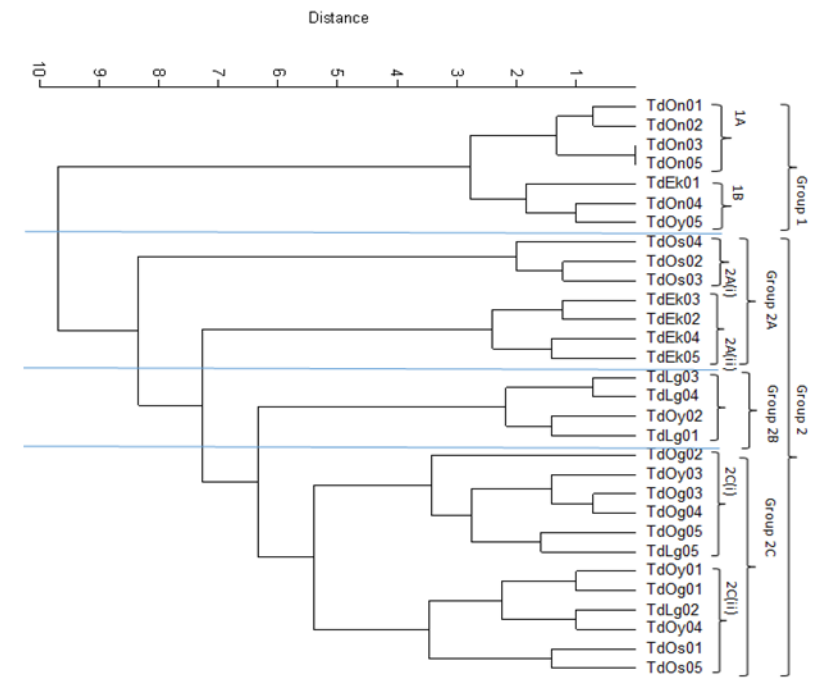

Fig. 6 Dendrogram generated using minimum dissimilarity distance base on UPGMA Ward's clustering method showing genetic relationship for morphometric and inter-simple sequence markers among Thaumatococcus daniellii populations in the southwestern region of Nigeria

Osun populations. Similarly, all Ekiti populations except TdEk01 clustered together (2Aii) at a genetic distance of 3. The sub-group $2 \mathrm{~B}$ had 3 members from Lagos and one from Oyo. Two clusters emanated from the sub-group 2C. Cluster 2C(i) had six heterogeneous members from Oyo, 
Ogun and Lagos populations, but populations from the same state are more similar based on the genetic distance scale. Also, members of the cluster $2 \mathrm{C}$ (ii) cut across all the states except Ekiti populations. At a genetic distance of about 1, the TdLg04 and TdOy02 which are Lagos and Oyo population respectively were similar. The pattern of clustering revealed that some populations within the state had a high degree of similarity, nonetheless, strong genetic relationship exists among populations from different states.

\section{Discussion}

Proper identification, documentation, conservation and estimation of variability among populations of a plant species are essential for the development of improved cultivars and sustainable utilization of the available genetic resources. Inadequate information on existing variability and genetic diversity of Thaumatococcus daniellii in the growing regions of West Africa has contributed to its underutilization and neglect. The morphometric variability observed in the studied populations of $T$. daniellii may be due to the differences in the microclimate, soil and available nutrient (Mayland and Wilkinson 1989; Zas 2003). For instance, the long petioles in TdEk02, TdEk03, TdEk05 (Ekiti); TdOn03 and TdOn04 (Ondo) populations could be attributed to shade effects as the plants grew under cocoa shades which necessitates competition for the sunlight that resulted into long petioles (Boadi et al. 2014). More so, the plant was reported as shade-loving herbs that flourish under partial shades of tree crops (Onwueme et al. 1979; Yeboah et al. 2003). Variations in leaf morphological traits could be governed by light availability and this may be functionally significance. However, ecosystem properties such as nutrient availability might also impact light-driven structure-function relationships (Stephens et al. 2009).

In an earlier report, Makinde and Taiwo (2004) elucidated that the general growth of $T$. daniellii depends on the climate of the area where it grows. Besides, soil properties such as $\mathrm{pH}$, organic carbon, and available nutrient element affect plant growth; as a combination of these factors among others determines the performance of the plant (Boadi 2011; Falconer 1990; Lu et al. 2000; Oyedeji et al. 2014). The broad leaves of most populations indicate the availability of the required plant nutrients in the soil, as soil nutrient was related to foliage development (Boadi 2011). Although the populations under study are within similar climatic (tropical rain forest) zone of Nigeria, the difference in soil compositions (Fagbemi and Shogunle 1995; Gbadegesin and Olabode 2000; Nwachokor and Uzu 2008) will to a large extent, influence variation in their growth. Furthermore, massive litter falls in the cocoa and kola nut plantations where some populations were located may ensure addition of organic matter into the soil which promotes plant growth as evident in Ekiti, Ondo and Ogun samples. By implication, the long petiole and broad leaves of Ekiti and Ondo Populations is the reason for its economic and folklore utilisation in mat weaving and making of thatch roof.

Earlier, significant relationships between foliar development and soil nutrient elements have been reported among $P$. radiata (Davis et al. 2007). However, there could be a great variation in plant growth due to age, season and/or climatic gradients, soil type and nutrient gradients (Foulds 1993). This may account for the morphometric variations observed in this study, the variability observed in the present s study agreed with the morphological variations noted by Waliszewski et al. (2012). Meanwhile, T. daniellii has been demonstrated to be adaptive and can grow at different sites with varied chemical properties and physical properties (Gunn et al. 1999). The significant and positive correlation of vegetative characters obtained here showed the traits are positively associated, the traits with significant positive associations are genetically linked and can be improved together. In exploring the genetic diversity of the population based on morphometric parameters, petiole length and leaf dimensions are the most effective in delimiting the populations. Positive correlation has been obtained for morphological and agronomic traits in crop plants (Azeez et al. 2017; Olorunmaiye et al. 2019).

Characterization and assessment of diversity using morphological and agronomic traits are often restricted and influence by environmental factors (Chen et al. 2014). Therefore, more reliable and precise techniques that rely on molecular markers is imperative. It is important, however, to note that markers are different in their actions and will reflect different aspects of genetic diversity (Tadesse 2017). The degree of loci and allelic polymorphism achieved with the ISSR markers employed in this study indicated the effectiveness of the markers for the diversity study. The populations exhibited considerable heterologous amplification of the alleles, which implies that the selected markers are effective in assessing the genetic variation of the populations. This agreed with earlier studies which demonstrated that microsatellite markers are effective in characterization and genotyping of crop plants (Ajibade et al. 2000; Rana et al. 2014; Animasaun et al. 2015, Olatunji and Afolayan 2019). Since a higher number of alleles and high polymorphism help to accurately estimate the genetic diversity 
of the population, marker profiles are usually interpreted in terms of allele phenotypes (Esslink et al. 2004). Thus the degree of polymorphism shows the extent of diversity and efficacy of the markers (Pfeifer et al. 2011). Polymorphic information of a molecular marker is related to the expected heterozygosity obtained from allelic frequency. Although the allelic frequency and polymorphic information contents of the ISSR markers used in this study revealed that most of the markers are effective, ISSR6, ISSR17, ISSR18 and ISSR19 are the most informative. Effectiveness of the markers in the study is in tandem with the previous reports on the use of molecular markers on diversity analysis of some members of the family Marentheceae which $T$. daniellii belongs (Rout et al. 2007; Waliszewski et al. 2012; Cirhorz et al. 2014; Chinedu et al. 2018).

The principal coordinate analysis (PCoA) based on the marker information showed that both morphometric and biological markers help delimit the populations. Populations that occupied the same quadrant are genetically related irrespective of their location and the climatic variations that applied. For instance, the occurrence of four Ondo populations (TdOn01, TdOn02, TdOn032, TdOn04) and a population from Oyo (TdOy05) on the same quadrant showed though the populations were from different states, they are related. It has been established that population, accessions or genotypes that clustered into a group based on their similarity, hence, they are genetically related (Tyagi et al. 2014, Animasaun et al. 2017, Olatuji and Afolayan 2019). Thus, populations from different locations and states may be relatives as obtained in the present study.

The dendrogram obtained in this study based on the UPMGA using Ward's method revealed that all the populations were related at a genetic distance less than 10 . Further separation of the populations into more clusters at lesser genetic distance signified the closeness and strong relationship of the members in a cluster. A similar clustering pattern was reported by Chinedu et al. (2018) for some T. daniellii and Megaphrynium macrostachyum populations. The clustering pattern of the dendrogram corroborated the spatial placement of the populations by the PCoA, therefore the relationships among the populations are consistent and genetic. The grouping of the populations across the states and locations showed the populations are similar, though they may be separated by geographical divergence. This further gives credence to the view of Animasaun et al. (2015) that genetically related accessions/genotypes will cluster together irrespective of their sources.

Low variability and poor gene pool can be of great negative consequences in a given plant species or population.
Some of the possible effects include; retards growth, poor vigour, susceptibility to diseases and genetic erosion among others (Rauf et al. 2010). The degree of diversity demonstrated in this study is sufficient to be harnessed for the improvement and sustainable utilization of the plant. Where populations from different states clustered, stronger bonds exist among populations from different locations within a state than those from different states. Such populations could have arisen from a common progenitor, but isolated by ecological factors, domestication and agricultural activities which ultimately resulted in different populations/genotypes that became stabilised over a while. Whichever population concept adopted from this study, whether phonetic (morphometric) or genomics, it is evident that there exist variation in the studied T. daniellii populations either within or across the states, and the variability could be harnessed for its improvement, conservation and sustainable utilisation.

\section{Conclusion}

In crop improvement and conservation for sustainable utilisations, knowledge of existing variability and genetic divergence of available populations and germplasm is important. To achieve this, diversity study using both morphometric and molecular marker is imperative. The morphometric and ISSR markers used in the current study delimited the populations and partitioned them based on their genetic relationships. The study showed the effectiveness of the markers for the genetic diversity of $T$. daniellii populations as it revealed existing variation among populations from different locations within a state and across the states. The information provided in this study could be used in identifying parents with good combining abilities to produce segregating progenies that can be used for further selection. The close relationship between some populations even across the states suggests a common origin and that the populations might have been isolated by anthropological, ecological or geographical mechanism.

\section{Acknowledgment}

The authors are thankful to the Management and Staff of Bioscience Laboratory, International Institute of Tropical Agriculture (IITA), Ibadan, Nigeria for allowing us to use their Laboratory and equipment. 


\section{Conflict of Interest}

The authors declare that they have no conflict of interest.

\section{Funding Information}

No funding was received for this study.

\section{References}

Adebisi AO, Adeoye IB, Olajide FB, Usman JM, Agbarevoh P, Oyedele $\mathrm{OO}(2010)$ Gender analysis of production, potentials and constraints of Thaumatococcus daniellii. J. Bot. 1:3-5

Adeyemi TOA, Idowu OD, Ogboru RO, Iyebor WE, Owoeye EA (2014) Phytochemical screening, nutritional and medicinal benefits of Thaumatococcus daniellii Benn (Benth.). Inter. J. Appli. Res. and Technol. 3(8):92-97

Ajibade SR, Weeden NF, Michite S (2000) Inter simple sequence repeat analysis of genetic relationships in the genus Vigna. Eupytical. 111:47-55

Animasaun DA, Morakinyo JA, Mustapha OT, Krishnamurthy R (2015) Assessment of genetic diversity in accessions of pearl millet (Pennisetum glaucum) and napier grass (Pennisetum purpureum) using micro satellite (ISSR) markers. Iranian J. Genet. Plant Breed. 4(1):25-35

Animasaun DA, Morakinyo JA, Krishnamurthy R, Mustapha OT (2017) Genetic divergence of Nigerian and Indian pearl millet accessions based on agronomical and morphological traits. J. Agric. Sci. 62(2):115-131

Arowosoge OGE, Popoola L (2006) Economic analysis of Thaumatococcus daniellii (Benn.) Benth. (Miraculous berry) in Ekiti State, Nigeria. Food, Agric. and Environ. 4(1):264-269

Azeez MA, Olowookere MB, Animasaun DA, Bello BO (2017) Utility of some floral characters in the assessment of genetic diversity in sesame (Sesamum indicum L.). Acta Agriculturae Slovenica. 109(1):61-70

Boadi SM (2011) Ecology, conservation, cultivation and management potential of Thaumatococcus daniellii for agroforestry system. A PhD Thesis, School of Graduate Studies, Kwame Nkrumah University of Science and Technology, Kumasi Ghana Pp 56-71

Boadi S, Baah-Acheamfour M, Ulzen-Appiah F, Jamro GM (2014) Nontimber forest product yield and income from Thaumatococcus daniellii under a mixed tree plantation system in Ghana. Int. J. Forest. Res. 2014(1). 10.1155/2014/524863.

Chen S, Pang X, Song J, Shi L, Yao H, Han J, Leon C (2014) A renaissance in herbal medicine identification: from morphology to DNA. Biotechnol. Adv. 32(7):1237-1244

Chinedu SN, Oluwadamisi AY, Popoola ST, David BJ, Epelle T (2014) Analyses of the leaf, fruit and seed of Thaumatococcus daniellii (Benth.): Exploring potential uses. Pak. J. Biol. Sci. 17:849-854
Chinedu SN, Emiloju OC, Iheagwam FN, Rotimi SO, Popoola JO (2018) Phylogenetic relationship and genetic variation among Thaumatococcus daniellii and Megaphrynium macrostachyum ecotypes in Southwest Nigeria. Asian J. Plant Sci. 17:27-36

Cichorz S, Goska M, Litwiniec A (2014) Miscanthus: Genetic diversity and genotype identification using ISSR and RAPD markers. Mol. Biotechnol. 56:911-924

Csurhes S, Edwards R (1998) Potential environmental weeds in Australia: Candidate species for preventative control. Environ. Australia. 3(5):208-215

Davis RM, Coker G, Parfitt RL, Simcock R, Clinton PW, Garrett LG, Watt MS (2007) Relationships between soil and foliar nutrients in young densely planted mini-plots of Pinus radiata and Cupressus lusitanica. Forest Ecol. and Manag. 240(1-3): 122-130

Elemo BO, Adu OB, Alabi AM (2001) Isolation and partial purification of carbohydrate component of Thaumatococcus danielli (Benth.). Nig. J. Biochem. and Molecular Biol. 16: $87-90$

Elemo BO, Adu OB, Ogunrinola OO, Efuwape TO, Olaleye KO, Kareem AA (2011) Biological evaluation of Thaumatococcus daniellii waste protein. Pakistan J. Nutri. 10(11):1048-1052

Esselink GD, Nybom H, and Vosman B (2004) Assignment of allelic configuration in polyploids suing the MAC-PR (Microsatellite DNA allele counting-peak ratios) method. Theor. Appl. Genet. 109:402-408

Fagbemi AA, Sogunle EAA (1995) Nigeria: Reference soil of the moist lowlands near Ife (Oshun State). Soil Brief Nigeria 3. University of Ibadan, Ibadan and International Soil Reference and Information Centre, Wagneingen. Pp 13

Falconer J (1990) The major significance of 'minor' forest products. The local use and value of forests in West African Humid Forest Zone. FAO, Rome. 59p

Foulds W (1993) Nutrient concentrations of foliage and soil in South-western Australia. New Phytologist, 125:529-546

Gbadegesin A, Olabode MA (2000) Soil properties in the metropolitan region of Ibadan, Nigeria: implications for the management of the urban environment of developing countries. The Environmentalist. 20:205-214

Gunn S, Farrar JF, Collis BE, Nason M (1999) Specific leaf area in barley: individual leaves versus whole plants. New Phycologist. 143:45-51 41

Liu F, Liang X, Zhang S (2000) Accumulation and utilization efficiency of potassium in ramie varieties. J. Plant Nutr. 23: 785-792

Makinde SO, Taiwo CK (2004) In situ population evaluation of $T$. daniellii (Benth). ASSET Inter. J. 3:75-80

Mayland FH, Wilkinson SR (1989) Soil factors affecting magnesium availability in plant-animal systems: A Review. J. Anim. Sci. 67:3437-3444

Mohapatra A, Rout GR (2005) Identification and genetic variation among rose cultivars using random amplified polymorphic DNA. Z. Naturforsch., 60c:611-617

Most BH, Summerfield RJ, Boxall M (1978) Tropical plants with sweetening properties, Thaumatococcus daniellii. Econ. Bot. 
$32: 321-335$

Ndukwe AA, Enoh EA, Aniere QU (2014) Determination of morphological and nutritional properties of Thaumatococcus daniellii and effect of harvesting method on the plant growth. Inter. J. Innov. and Scienti. Res. 11(2):304-311

Nwachokor MA, Uzu FO (2008) Updated classification of some soil series in southwestern Nigeria. J. Agrono. 7(1):76-81

Ogunsanwo OY, Adedeji GA, Ajibabi AS (2012) Pulping potential of Thaumatococcus daniellii (Benn) Benth in Omo and Oban Forest Reserve of Nigeria. I.J.S.N., 3(2):580-585

Ojekale AB, Makinde SCO, Osileye O (2007) Phytochemistry and antimicrobial evaluation of Thaumatococcus danielli Benn. (Benth.) leaves. Nigeria Food Journal, 25(2):176-183

Olatunji TL, Afolayan AJ (2019) Evaluation of genetic relationship among varieties of Capsicum annuum L. and Capsicum frutescens L. in West Africa using ISSR markers. Heliyon 5(2019): 01700

Olorunmaiye KS, Joseph GG, Animasaun DA, Oyedeji S (2019) Mutagenic components and dosage effects of ethyl methanesulphonate on Arachis hypogea (SAMNUT 24 VR.). Ife J. Sci. 21(2):309-322

Onwueme IC, Onochie BE, Safowora EA (1979) Cultivation of $T$. daniellii the sweetener, World Crop. SAS Institute, 2012. SAS user's guide: Statistics SAS/C Online Doc, Release 9.20, SAS, Cary, NC, U.S.A. 106p

Oyedej S, Animasaun DA, Bello AA, gboola, OO (2014) Effect of NPK and Poultry manure on growth, yield and proximate composition of three Amaranths. Journal of Botany. (Vol. 2014) http://dx.doi.org/10.1155/2014/828750

Paterson AH, Tanksley SD, Sorrels ME (1991) DNA markers in plant improvement. Adv. Agron. 46:39-90

Pfeiffer T, Roschanski AM, PannellKorbecka G, Schnitter M (2011) Characterization of microsatellite loci and reliable genotyping in a polyploidy plant, Mercurialis perennis (Euphorbiaceae). The J. Hered. 102:479-488

Rana M, Sharma R, Sharma P (2014) Estimation of genetic diversity in Capsicum annum $\mathrm{L}$. germplasm using PCR-based molecular markers. Natl. Acad. Sci. Lett. 37 (3):295-301

Rauf S, da Silva JAT, Khan AA, Naveed A (2010) Consequences of plant breeding on genetic diversity. Int. J. Plant Breed. 41:1-21

Rout GR, Senapati SK, Aparajita S (2007) Studies on the genetic relationship among 13 cultivars of Calathea (Marentheceae) using RAPD and ISSR markers. Adv. Hortic. Sci., 21:
$147-155$

Sofowora A (1993) Medicinal plants and medicine in Africa. John Wiley spectrum books, Ibadan, Nigeria, Pp 120-123

Sotannde OA, Oluwadare AO (2014) Fibre and elemental contents of Thaumatococcus daniellii stalk and its implications as a non-wood fibre source. Inter. J. Appli Sci. and Technolo. 4(1): 178-185

Stephens EL, Saha S, Menges ES (2009) Intracanopy variation in leaf morphology and physiology in dominant shrubs of Florida's xeric uplands. Botany, 87(1):112-125

Swift KAD, Pearce S, Roth H(2002) Out of Africa: The Chemistry and flavour properties of the protein thaumatin. In: Swift, K. A. D. (ed). Advances in flavours and fragrances; from the sensation to the synthesis. Royal Society of Chemistry, UK Pages 178-193

Tadesse A (2017) Inter Simple Sequence Repeat (ISSR) Markers for Genetic Diversity Studies in Trifolium Species. Advan. Life Sci. and Technol. 55:34-37

Thorn B (2004) Chefs find banana leaves appealing: natural foodwrapper, an authenticway to showcase tropical, ethnic foods. Nations Restaurant News, November 8, 2004

Tyagi AK, Sharma MK, Surya MSK, Kerkhi SA, Chand P (2014) Estimates of genetic variability, heritability and genetic advance in linseed (Linum usitatissinum L.) germplasm. Prog. Agric. 14(1):37-48

Van Der Wel H, Loeve K (1972) Isolation and characterization of thaumatin I and 11, the Sweet -Tasting Proteins from Thaumatococcus daniellii Benth. Eur. J. Biochem. 31: 221-225

Waliszewski WS, Sinclair FL, Steele KA (2012) Morphological and AFLP diversity in Thaumatococcus daniellii, the source of the protein sweetener thaumatin. Genet. Resour. Crop Evol. 59:151-161

Williams JGK, Kubelik AR, Livak KJ, Rafalski JA, Tingey SV (1990) DNA polymorphisms amplified by arbitrary primers are useful as genetic markers. Nucleic Acids Res., 18:6531-6535

Yeboah SO, Hilger TH, Kroschel J (2003) Thaumatococcus danielli (Benth): A natural sweetener from the rain forestzone in West Africa with potential income generation in small scale farming. J. Applied Sci. 6:854-859

Zas R (2003) Foliar nutrient status and tree growth response of young Pseudotsuga menziesii Mirb. (Franco) to nitrogen, phosphorus and potassium fertilization in Galicia (Northwest Spain). Journal of Ecology, 12(1):75-85 